\title{
Gangguan Gizi Balita di Desa Mekargalih Kecamatan Jatinangor - Sumedang: Masalah Kesehatan Masyarakat
}

\author{
R. Tina Dewi Judistiani ${ }^{1}$, Annisa Fauziah ${ }^{2}$, Sri Astuti $^{3}$, Anita Yuliani ${ }^{4}$, Puspa Sari ${ }^{4}$ \\ ${ }^{1}$ Departemen Epidemiologi dan Biostatistik Fakultas Kedokteran Universitas Padjadjaran \\ ${ }^{2}$ Program Studi Diploma IV Kebidanan Fakultas Kedokteran Universitas Padjadjaran \\ ${ }^{3}$ Departemen Ilmu Kesehatan Masyarakat Fakultas Kedokteran Universitas Padjaran \\ ${ }^{4}$ Departemen Ilmu Gizi Medik Fakultas Kedokteran Universitas Padjadjaran
}

\begin{abstract}
Abstrak
Penanggulangan gangguan gizi balita membutuhkan tindak lanjut yang terencana hingga level layanan primer. Data dasar dibutuhkan untuk menilai besarnya beban masalah tersebut. Penelitian deskriptif potong lintang dilakukan bulan Maret 2015 di Desa Mekargalih Kecamatan Jatinangor, yang termasuk wilayah asuhan Program Studi Diploma 4 Kebidanan Fakultas Kedokteran Unpad. Telah dikumpulkan data primer antropometri, usia dan jenis kelamin balita usia 3-5 tahun. Analisis indikator merujuk pada kurva World Health OrganizationNational Center for Health Statistics (WHO-NCHS) sesuai SK Menkes RI no 1995/Menkes/SK/XII/2010. Hasil penelitian menunjukkan komposisi balita 3-5 tahun di Desa Mekargalih terdiri atas 65 (38,9\%) anak laki laki dan 102 (61,1\%) anak perempuan. Besar masalah gizi buruk-kurang mencapai 10,8\%, wasting $7,8 \%$ dan stunting sebesar $16,2 \%$. Perbandingan proporsi balita yang mengalami gangguan gizi antara balita perempuan terhadap laki-laki adalah: $12,8 \%$ vs 7,7\% (gizi buruk-kurang), $18,6 \%$ vs $12,3 \%$ (stunting). Proporsi wasting pada balita perempuan lebih rendah (7,9\% vs 9,2\%). Gangguan gizi balita usia 3-5 tahun di Desa Mekargalih Kecamatan Jatinangor merupakan masalah kesehatan masyarakat tingkat sedang. Balita perempuan lebih rentan mengalami gangguan gizi. Perlu diupayakan perbaikan gizi terpadu bagi tiap individu dengan pendampingan tenaga kesehatan.
\end{abstract}

Kata Kunci : Balita, masalah kesehatan masyarakat, status gizi

\section{Malnutrition among Toddlers at Mekargalih Village, Jatinangor District - Sumedang : a Public Health Problem}

\begin{abstract}
Measurement of weight and height among toddlers at Mekargalih Village, Jatinangor District Sumedang are done routinely. As part of community service target area of Midwifery School - Faculty of Medicine Universitas Padjadjaran, it is important to assess whether nutritional problem has become a community health problem. A descriptive cross sectional study was carried out in March 2015. Primary anthropometry data (weight, height) as well as sex and age were collected from toddlers aged 3-5 years old. The World Health Organization- National Center for Health Statistics (WHO-NCHS) growth chart was used as reference, based on Ministry of Health Republic of Indonesia decree No 1995/Menkes/SK/XII/2010. A total population of 167 toddlers, 65 males dan 102 females, had participated. Results showed that nutritional deficiency has become a public health problem in moderate level, comprised of $10.8 \%$ underweight, $7.8 \%$ of wasting and $16.2 \%$ stunting. Female toddlers are more likely to be affected by underweight and wasting compared to males $(12.8 \%$ vs $7.7 \%$ and $18.6 \%$ vs $12.3 \%$ respectively), but less likely to experience wasting (7.9\% vs $9.2 \%)$. This research concluded that nutritional deficiency among toddlers has become a public health problem in Mekargalih Village, Jatinangor District Sumedang. Female were more prone than male toddlers. Comprehensive measures in nutrition fulfillment by health professionals in the field need to be developed individually.
\end{abstract}

Keywords: Nutritional deficiency, Public Health Problem, Toddler

Korespondensi :

Dr. R. Tina Dewi Judistiani, dr., SpOG

Departemen Epidemiologi dan Biostatistik Fakultas Kedokteran Universitas Padjadjaran

Jl. Eijkman No. 38 Bandung

Mobile : 0811249731

Email :judistiani@gmail.com 


\section{Pendahuluan}

Masa balita merupakan periode emas pertumbuhan fisik, mental dan emosional anak. Kebutuhan akan asah, asih, dan asuh yang memadai pada usia ini akan meningkatkan kelangsungan hidup anak dan mengoptimalkan kualitas anak sebagai generasi penerus bangsa. Balita yang mengalami hambatan atau gangguan pertumbuhan dan perkembangan akan berdampak pada periode kehidupan selanjutnya. Gizi baik akan menurunkan angka kesakitan, kecacatan, dan kematian balita, serta menekan pengeluaran pemerintah untuk menanggulangi kesakitan dan kecacatan akibat gangguan gizi tersebut.

Status gizi balita masih menjadi salah satu indikator keberhasilan pelayanan kesehatan. ${ }^{1}$ Status gizi balita diukur berdasarkan umur (U), berat badan (BB), dan tinggi badan/ panjang badan (TB). Variabel U, BB, dan TB ini diolah menjadi tiga indikator antropometri, yaitu: berat badan menurut umur $(\mathrm{BB} / \mathrm{U})$, tinggi badan menurut umur $(\mathrm{TB} / \mathrm{U})$, dan berat badan menurut tinggi badan (BB/TB). Indikator $\mathrm{BB} / \mathrm{U}$ memberikan indikasi masalah gizi secara umum, karena tidak memberikan informasi mengenai patofisiologi gangguan gizi tersebut. Indikator gizi $\mathrm{TB} / \mathrm{U}$ memberi informasi tentang gangguan gizi kronis sebagai akibat dari keadaan patologis yang berlangsung lama, misalnya kemiskinan, perilaku hidup tidak sehat dan pola asuh/pemberian makan yang kurang baik dari sejak anak dilahirkan yang mengakibatkan anak menjadi pendek. Indikator BB/TB dan Indeks Massa Tubuh (IMT) memberikan indikasi masalah gizi yang sifatnya akut, misalnya gangguan karena kurangnya asupan saat anak sedang sakit berat dalam periode yang singkat. ${ }^{1,2}$

Berdasarkan hasil Riset Kesehatan Dasar tahun 2013 prevalensi berat kurang (underweight) nasional sebesar $19,6 \%$, sedangkan target MDGs tahun $201515,5 \%$, maka prevalensi gizi berat kurang harus diturunkan sebesar 4.1\% dalam waktu 2 tahun. Dalam tahun 2013 prevalensi anak pendek (stunting) nasional sebesar 37,2 dan prevalensi kurus (wasting) sebesar 12,1\%. ${ }^{3,4}$ Menurut WHO masalah underweight $\mathrm{di}$ atas masuk dalam katagori sedang sedangkan untuk masalah stunting dan wasting masuk dalam batas tinggi atau serius. Penanggulangan masalah gizi dengan prevalensi yang cukup tinggi ini membutuhkan kerja keras untuk mencapai target di akhir tahun 2015. ${ }^{2}$

Penanganan masalah gizi membutuhkan pengelolaan yang terkoordinasi pusat namun harus mencapai akar masalah di level pedesaan. Berbagai sumber daya yang terdapat dalam sisten kesehatan nasional perlu diberdayakan termasuk sumber daya potensial tenaga kesehatan dalam masa pendidikan. Fakultas Kedokteran Universitas Padjadjaran telah menjadikan wilayah kecamatan Jatinangor sebagai salah satu wilayah binaan. Berdasarkan profil Puskesmas Kecamatan Jatinangor tahun 2012 mencantumkan bahwa proporsi balita dengan gizi buruk paling tinggi terdapat di Desa Mekargalih atas dasar indikator $\mathrm{BB} / \mathrm{U}$, yakni gizi buruk 5 kasus $(1,2 \%)$, gizi kurang 37 kasus $(8,7 \%)$, gizi baik 372 kasus $(87,9 \%)$, dan gizi lebih 9 kasus $(2,1 \%){ }^{5}$

Kelompok anak balita merupakan kelompok yang tersering menderita kekurangan gizi. Adanya gizi buruk akan memiliki dampak kelainan pada anak yang luas, sebagian merupakan kelainan yang dapat diamati sedangkan sebagian lainnya merupakan kelainan yang tersembunyi. Adanya ganggu perkembangan otak merupakan salah satu kelainan tersembunyi, hingga kemudian dampaknya secara klinis mungkin dapat diamati. Pemahaman tentang gangguan perkembangan anak tersebut sesungguhnya dapat diamati oleh orang orang yang memberikan asuhan, namun rendahnya tingkat pendidikan mereka mungkin berakibat pada lambatnya deteksi dini. Keterlambatan deteksi gangguan gizi dan perlembangan anak akan berpengaruh pada kehidupan anak sejak usia prasekolah. ${ }^{6}$

Komposisi asupan gizi anak berperan penting. Kekurangan energi, protein, vitamin dan trace element dapat mengganggu pertumbuhan, namun sebaliknya konsumsi berbagai elemen nutrisi mikro berlebihan diduga dapat mengganggu pertumbuhan dan perkembangan. Kecukupan gizi seseorang perlu diperhatikan dengan mengacu pada kebutuhan gizi yang menggambarkan banyaknya zat gizi minimal yang diperlukan oleh masing-masing individu secara umum. Untuk kelompok balita 1-3 tahun sebesar 1200 kalori sedangkan pada kelompok usia 4-6 tahun sebesar 1500 kalori pada tingkat konsumsi, dengan tambahan konsumsi trace element tertentu. Hal ini ditetapkan melalui Peraturan Menteri Kesehatan Republik Indonesia Nomor 75 Tahun 2013 tentang Angka Kecukupan Gizi Yang Dianjurkan Bagi Bangsa Indonesia.

Asupan gizi yang baik acapkali tak dapat diperoleh seorang anak atas alasan internaleksternal yang beragam danbersifat multifaktorial. Berbagai penelitian menunjukkan hasil yang kontradiktif tentang hubungan berbagai faktor (genetik, umur anak, jenis kelamin anak, usia orang tua, tingkat pendidikan orang tua, pekerjaan orang tua balita, jumlah tanggungan dalam satu keluarga, kondisi ekonomi keluarga) dengan status gizi anak. ${ }^{8-10}$ Pertumbuhan dan perkembangan anak merupakan dua kondisi yang memiliki hubungan timbal balik, karena setiap sisi 
akan saling mempengaruhi sisi lainnya. Dalam hal tersebut pola asuh yang diterima seorang anak akan menentukan luaran yang diperoleh. ${ }^{11}$

Tujuan dari penelitian ini adalah untuk mengetahui gambaran masalah gizi balita 3-5 tahun menggunakan indikator $(\mathrm{BB} / \mathrm{U}),(\mathrm{TB} / \mathrm{U})$ dan $(\mathrm{BB} / \mathrm{TB})$ serta besarnya masalah gangguan gizi di desa Mekargalih sebagai daerah binaan Prodi Diploma 4 Kebidanan Fakultas Kedokteran Universitas Padjadjaran. Selanjutnya data ini dapat digunakan untuk menentukan langkah apa yang perlu dilakukan Bidan mitra keluarga sebagai sebuah program inovasi upaya meningkatkan kemaslahatan bagi masyarakat.

\section{Metode}

Penelitian deskriptif potong lintang telah dilakukan pada balita usia 3-5 tahun di Desa Mekargalih Kecamatan Jatinangor pada bulan Maret 2015. Kriteria inklusi adalah balita tersebut tercatat sebagai penduduk wilayah penelitian, dan dilakukan eksklusi bila balita tidak berada di tempat, anak sakit atau tidak kooperatif saat penelitian berlangsung atau dalam 2 bulan terakhir menetap di luar wilayah Mekargalih. Penelitian ini merupakan bagian dari penelitian Kohor Ibu Bayi Balita Jatinangor dan telah mendapat persetujuan etik dari Komite Etik Penelitian Kesehatan Universitas Padjadjaran

Data primer pengukuran antropometri, jenis kelamin dan umur dikumpulkan kemudian dianalisis dengan merujuk pada ketentuan WHO yaitu menghitung Z-Score atau menggunakan grafik pertumbuhan rujukan WHO-National Center for Health Statistics (WHO-NCHS) sesuai SK Menkes RI no 1995/Menkes/SK/XII/2010. ${ }^{12}$ Penghitungan Z-score dilakukan menggunakan rumus berikut :

$$
\begin{aligned}
& \text { z-skor }= \text { (nilaihasilukursubjek)-(nilaimedian } \\
& \text { pada kelompok umur yang sama) }
\end{aligned}
$$

z-skor pada referensi populasi

Penggunaan grafik pertumbuhan yang dikeluarkan WHO untuk kepentingan pengumpulan data lapangan lebih praktis, mengingat Z-score dapat langsung ditentukan dengan melakukan proyeksi hasil pengukuran $\mathrm{BB}$ dan $\mathrm{TB}$ pada kurva pertumbuhan yang sesuai dengan kelompok umur dan jenis kelamin masing masing anak (gambar 1). ${ }^{2,13}$

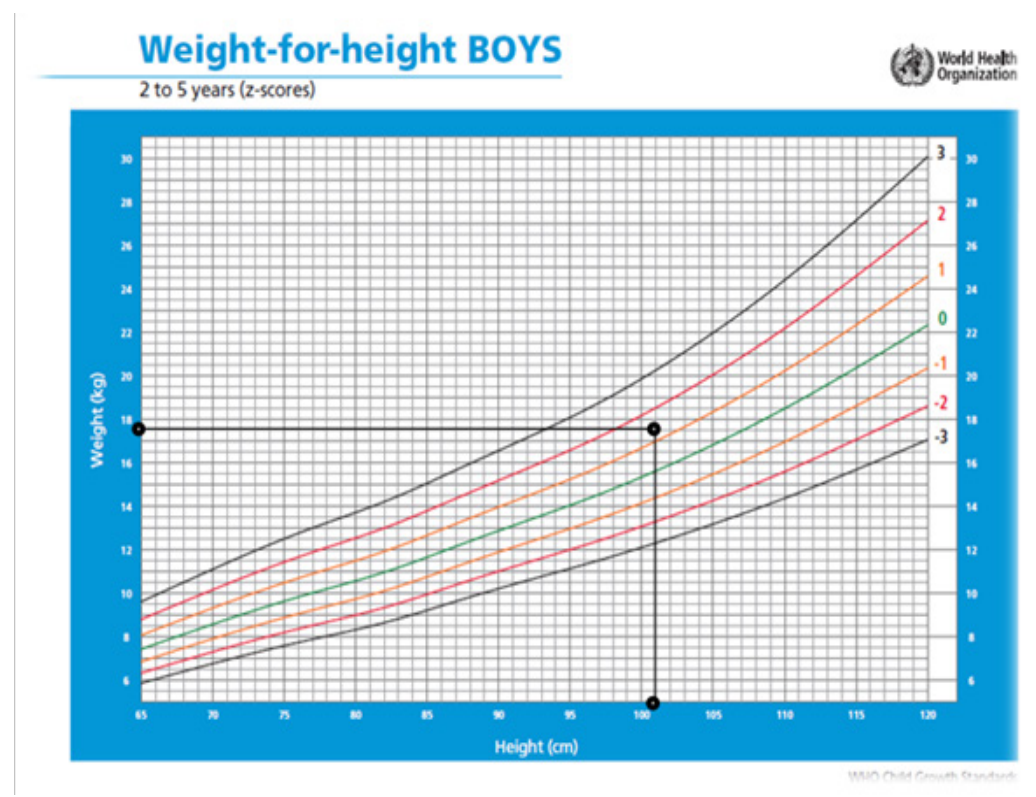

Gambar 1 Grafik Pertumbuhan WHO

Sumber : Global Database on Child Growth and Malnutrition ${ }^{2}$ dan WHO Multicentre Growth Reference Study Group ${ }^{13}$ 
Berdasarkan Z-score yang diperoleh dapat ditentukan status gizi seorang anak, menurut indikator yang diinginka, dengan dasar kalsifikasi pada pada tabel 1. Selanjutnya akumulasi data status gizi anak pada suatu wilayah dapat digunakan untuk menghitung prevalensi setiap masalah gizi yang ada sesuai indikator.

Besarnya gangguan gizi balita sebagai masalah kesehatan masyarakat ditentukan menurut jenis gangguan gizi yang terjadi karena masing-masing jenis gangguan memiliki batasan yang berbeda seperti tampak pada tabel 2 .

Tabel 1. Klasifikasi Status Gizi Berdasarkan Z-Score Standar Baku Antropometri WHONCHS

\begin{tabular}{ccc}
\hline $\begin{array}{c}\text { Indeks } \\
\text { Berdasarkan }\end{array}$ & Status Gizi & $\begin{array}{c}\text { BB/TB } \\
\text { (Z-Skor) }\end{array}$ \\
\hline & Gizi Buruk & $<-3$ \\
Indeks BB/U & Gizi Kurang & $-3 \mathrm{~s} / \mathrm{d}<-2$ \\
& Gizi Baik & $-2 \mathrm{~s} / \mathrm{d} 2$ \\
& Gizi Lebih & $>2$ \\
\hline & Sangat pendek & $<-3$ \\
Indeks TB/U & Pendek & $-3 \mathrm{~s} / \mathrm{d}<-2$ \\
& Normal & $-2 \mathrm{~s} / \mathrm{d} 2$ \\
& Tinggi & $>2$ \\
\hline & Sangat Kurus & $<-3$ \\
& Kurus & $-3 \mathrm{~s} / \mathrm{d}<-2$ \\
Indeks BB/TB & Normal & $-2 \mathrm{~s} / \mathrm{d} 2$ \\
& Gemuk & $>2$ \\
\hline
\end{tabular}

Sumber : www.who.int Global Database on Child Growth and Malnutrition ${ }^{2}$

Semakin buruk tingkat gangguan gizi yang terjadi pada seoran anak, semakin cepat intervensi perlu dilakukan untuk menghindari mortalitas maupun morbiditas lanjut terkait gangguan gizi pada anak.

Tabel 2. Klasifikasi Masalah Gizi Sebagai Masalah Kesehatan Masyarakat

\begin{tabular}{l|c|c|c|c}
\hline Masalah Gizi & Rendah & Sedang & Tinggi & $\begin{array}{l}\text { Sangat } \\
\text { Tinggi }\end{array}$ \\
\hline Stunting & $<20$ & $20-29$ & $30-39$ & $\geq 40$ \\
Underweight & $<10$ & $10-19$ & $20-29$ & $\geq 30$ \\
Wasting & $<5$ & $5-9$ & $10-14$ & $\geq 15$ \\
\hline
\end{tabular}

Keterangan: Angka menunjukan besar prevalensi Sumber: www.who.int Global Database on Child Growth and Malnutrition ${ }^{2}$

\section{Hasil}

Pada penelitian ini total balita usia 3-5 tahun pada bulan Maret 2015 di Desa Mekargalih Kecamatan Jatinangor berjumlah 188 anak. Balita yang memenuhi kriteria inklusi untuk dijadikan sampel berjumlah 167 anak. Anak yang tidak memenuhi kriteria seperti anak sedang sakit, tidak datang karena alasan tertentu, anak yang sudah tinggal di luar wilayah desa lebih dari dua bulan, dan anak rewel tidak mau dites berjumlah 21 anak. Penilaian status gizi balita diperoleh dari hasil pemeriksaan antopometri yang hasilnya dimasukkan ke dalam grafik pertumbuhan WHO dan untuk penafsirannya dapat dilihat berdasarkan indeks yang digunakan.

Berdasarkan tabel 3 didapatkan data bahwa dari 167 anak yang dinilai dengan indikator $\mathrm{BB} / \mathrm{U}$, sebanyak 146 anak $(87,4 \%)$ dalam status gizi baik. Delapan belas anak (10,8\%) mengalami berat-kurang (underweight), dengan rincian 3 orang $(1,8)$ dengan status gizi buruk dan 15 orang dengan status gizi kurang $(9,0 \%)$. Terdapat 3 orang dengan status gizi lebih $(1,8 \%$

Tabel 3 juga menunjukkan bahwa prevalensi balita yang terhambat mencapai tinggi tubuh yang diharapkan di Desa Mekargalih pada bulan Maret 2015 sebanyak 27 anak (16,2\%) dengan rincian 22 anak $(13,2 \%)$ berperawakan pendek, bahkan 5 anak $(3,0 \%)$ berperawakan sangat pendek. Terdapat juga anak dengan perawakan tinggi sebanyak 3 orang $(1,8 \%)$. Selebihnya anak usia 3-5 tahun di Desa Mekargalih berperawakan normal sebesar 82,0\%.

Prevalensi gangguan gizi wasting berdasarkan $\mathrm{BB} / \mathrm{TB}$ sebesar $7,8 \%$ dengan rincian status gizi kurus $(6,0 \%)$ dan status gizi buruk atau sangat kurus $(1,8 \%)$. Namun, terdapat juga anak dengan status gizi gemuk sebanyak 8 orang $(4,8 \%)$ sisanya memiliki status gizi normal sebesar $87,4 \%$.

Tabulasi silang berbagai indikator gangguan gizi balita pada bulan Maret 2015 di desa Mekargalih ditampilkan pada tabel 4.

Perhatian khusus perlu diberikan pada balita yang mengalami gangguan gabungan dari ketiga indikator yang digunakan, karena pada kelompok ini risiko balita mengalami morbiditas tambahan menjadi lebih besar. Terdapat 1 anak dengan status gizi pendek-sangat kurus, karena hal ini menunjukkan bahwa gangguan kekurangan gizi yang dideritanya sangat berat. Sedangkan 1 anak yang termasuk katagori gemuk dan berperawakan tinggi juga perlu mendapatkan perhatian mengingat pola asuh yang salah dengan memberikan makanan jauh melebihi kebutuhannya akan meningkatkan risiko penyakit sindroma metabolik pada usia yang dewasa muda.

Selanjutnya penulis melakukan kajian 
Tabel 3. Distribusi Frekuensi Status Gizi Anak Usia 3-5 Tahun di Desa Mekargalih Kecamatan Jatinangor Sumedang bulan Maret 2015

\begin{tabular}{ccc}
\hline Status Gizi & Frekuensi & Persentase (\%) \\
\hline Klasifikasi berdasarkan berat badan menurut umur (BB/U) & \\
Gizi Buruk & 3 & 1,8 \\
Gizi Kurang & 15 & 9,0 \\
Gizi Baik & 146 & 87,4 \\
Gizi Lebih & 3 & 1,8 \\
Klasifikasi berdasarkan tinggi badan menurut umur (TB/U) & \\
Sangat Pendek & 5 & 3,0 \\
Pendek & 22 & 13,2 \\
Normal & 137 & 82,0 \\
Tinggi & 3 & 1,8 \\
Klasifikasi berdasarkan berat badan menurut tinggi badan (BB/TB) & \\
Sangat Kurus & 3 & 1,8 \\
Kurus & 10 & 6,0 \\
Normal & 146 & 87,4 \\
Gemuk & 8 & 4,8 \\
\hline
\end{tabular}

Tabel 4. Distribusi Frekuensi Status Gizi Anak Usia 3-5 Tahun Berdasarkan Gabungan Indikator di Desa Mekargalih Kecamatan Jatinangor Sumedang Bulan Maret 2015

\begin{tabular}{|c|c|c|c|c|c|}
\hline \multirow{2}{*}{ Status Gizi } & \multicolumn{4}{|c|}{ Indikator $\mathrm{BB} / \mathrm{TB}$} & \multirow{2}{*}{ Total } \\
\hline & Sangat Kurus & Kurus & Normal & Gemuk & \\
\hline Sangat Pendek & 0 & 0 & 5 & 0 & 5 \\
\hline Pendek & 1 & 0 & 21 & 0 & 22 \\
\hline Normal & 2 & 10 & 118 & 7 & 137 \\
\hline Tinggi & 0 & 0 & 2 & 1 & 3 \\
\hline
\end{tabular}

terhadap sebaran gangguan gizi menurut jenis kelamin balita yang diteliti, yang ditampilkan pada tabel 5. Prevalensi underweight dan stunting pada kelompok anak perempuan ternyata lebih tinggi dibandingkan anak laki-laki.

Prevalensi underweight pada kelompok anak perempuan telah mencapai tingkat masalah kesehatan masyarakat tingkat sedang, dan berkontibusi cukup besar pada prevalensi underweight secara keseluruhan (13 dari total 18 kasus) di tingkat Desa Mekargalih

Prevalensi wasting pada anak laki-laki lebih tinggi $(9,2 \%)$ bila dibandingkan anak perempuan (7,9\%). Pada kedua kelompok jenis kelamin masalah wasting termasuk masalah kesehatan masyarakat tingkat sedang.

\section{Pembahasan}

Pada penelitian ini digunakan beberapa indikator untuk mengetahui status gizi balita. Dari hasil pengukuran didapatkan status gizi yang berbeda dari setiap balita yang diteliti. Secara kumulatif masalah gizi yang terjadi di wilayah Desa MekargalihKecamatan Jatinangor Sumedang pada bulan Maret 2015 adalah masalah underweight $(10,8 \%)$ dan wasting $(7,8 \%)$, keduanya termasuk dalam katagori masalah kesehatan masyarakat tingkat sedang.2 Perlu dilakukan penanganan yang tepat guna dan tepat sasaran agar masalah gizi tersebut tidak masuk dalam katagori yang lebih parah bahkan seharusnya prevalensinya turun. Jika dibandingkan dengan data tahun 2012, maka prevalensi underweight sedikit meningkat dari 9,8\% menjadi $10,8 \% .^{5}$ 
Tabel 5. Distribusi Frekuensi Status Gizi Anak Usia 3-5 Tahun Berdasarkan Jenis Kelamin Desa Mekargalih Kecamatan Jatinangor bulan Maret 2015

\begin{tabular}{lcccc}
\hline \multirow{2}{*}{ Indikator } & \multicolumn{2}{c}{ Laki-Laki } & \multicolumn{3}{c}{ Perempuan } \\
\cline { 2 - 5 } & $\mathbf{( f )}$ & $\mathbf{( \% )}$ & $\mathbf{( F )}$ & $\mathbf{( \% )}$ \\
\hline Indikator BB/U & & & & \\
Gizi Buruk & 2 & 3,1 & 1 & 1,0 \\
Gizi Kurang & 3 & 4,6 & 12 & 11,8 \\
Gizi Baik & 58 & 89,2 & 88 & 86,3 \\
Gizi Lebih & 2 & 3,1 & 1 & 1,0 \\
Indikator TB/U & & & & \\
Sangat pendek & 1 & 1,5 & 4 & 3,9 \\
Pendek & 7 & 10,8 & 15 & 14,7 \\
Normal & 54 & 83,1 & 83 & 81,4 \\
Tinggi & 3 & 4,6 & 0 & 0 \\
Indikator BB/TB & & & & 1,0 \\
Sangat kurus & 1 & 1,5 & 1 & 6,9 \\
Kurus & 5 & 7,7 & 7 & 89,2 \\
Normal & 57 & 87,7 & 91 & 2,9 \\
Gemuk & 2 & 3,1 & 3 & \\
\hline
\end{tabular}

MasalahstuntingpadabalitadiDesamekargalih Kecamatan Jatinangor Sumedang pada bulan Maret 2016 dengan prevalensi $16,2 \%$ termasuk dalam katagori masalah kesehatan masyarakat tingkat rendah. Akan tetapi hendaknya ini tetap menjadi indikator upaya perbaikan gizi balita di masyarakat. Ringkasan kajian ibu dan anak dari UNICEF Indonesia menyebutkan bahwa masalah gizi, khususnya anak pendek, menghambat perkembangan anak muda, dengan dampak negatif yang akan berlangsung dalam kehidupan selanjutnya. ${ }^{14}$ Anak pendek sangat berhubungan dengan prestasi pendidikan yang buruk, lama mengenyam pendidikan lebih singkat dan pendapatan yang rendah sebagai orang dewasa. Anak-anak pendek menghadapi kemungkinan yang lebih besar untuk tumbuh menjadi orang dewasa yang kurang berpendidikan, miskin, kurang sehat dan lebih rentan terhadap penyakit tidak menular. Oleh karena itu, anak pendek merupakan prediktor buruknya kualitas sumber daya manusia yang diterima secara luas, yang selanjutnya menurunkan kemampuan produktif suatu bangsa di masa yang akan datang. ${ }^{14}$

Balita usia prasekolah atau usia 3- 5 tahun merupakan konsumen aktif yaitu mereka sudah dapat memilih makanan yang disukainya. Perilaku makan sangat dipengaruhi oleh keadaan psikologis, kesehatan dan sosial anak. Pada usia ini kebutuhan zat gizi meningkat karena masih berada pada masa pertumbuhan cepat dan aktivitasnya tinggi. Demikian juga anak sudah mempunyai pilihan terhadap makanan yang disukai termasuk makanan jajanan. Oleh karena itu jumlah dan variasi makanan harus mendapatkan perhatian secara khusus dari ibu atau pengasuh anak, terutama dalam memberikan paparan pilihan makanan sehat dengan gizi seimbang. Disamping itu anak pada usia ini senang bermain keluar rumah sehingga lebih mudah terkena penyakit infeksi dan kecacingan terutama bagi mereka yang sudah memiliki masalah gangguan gizi. Terhadap kelompok berisiko ini upaya pemaparan terhadap perilaku hidup bersih sangat penting untuk dilakukan. ${ }^{15-17}$

Faktor makanan dan penyakit infeksi, sebagai penyebab langsung masalah gizi, keduanya saling berkaitan. Anak balita yang tidak mendapat cukup makanan bergizi seimbang memiliki daya tahan yang rendah terhadap penyakit sehingga mudah terserang infeksi. Sebaliknya penyakit infeksi seperti diare dapat mengakibatkan zat gizi tidak dapat diserap tubuh dengan baik sehingga berakibat buruk. Oleh karena itu, mencegah terjadinya infeksi juga dapat mengurangi kejadian gizi kurang dan gizi buruk. ${ }^{17}$

Konsumsi makanan yang beragam, bergizi seimbang dan aman dapat memenuhi kecukupan gizi individu untuk tumbuh dan berkembang. 
Makanan gizi seimbang yaitu asupan nutrisi yang cukup secara kuantitas, cukup secara kualitas, mengandung berbagai zat gizi (energi, protein, vitamin dan mineral) yang diperlukan tubuh untuk tumbuh (pada anak-anak), untuk menjaga kesehatan dan untuk melakukan aktivitas dan fungsi kehidupan sehari-hari (bagi semua kelompok umur dan fisiologis), serta menyimpan zat gizi untuk mencukupi kebutuhan tubuh saat konsumsi makanan tidak mengandung zat gizi yang dibutuhkan. ${ }^{7}$

Dampak dari kekurangan, berlebihan atau tidak seimbangnya asupan nutrisi dari protein, energi atau zat gizi mikro (vitamin dan mineral) disebut dengan malnutrisi. Tidak terpenuhi asupan nutrisi pada anak disebut dengan kurang gizi (undernutrition), sebagai hasil dari asupan makanan tidak cukup, perawatan yang tidak memadai dan adanya penyakit menular. Terdapat dua jenis kekurangan gizi diantaranya adalah KEP (kekurangan energi protein) yang muncul akibat kurangnya asupan kalori dari protein, seperti ikan dan daging, dan vitamindan mineral,seperti seng, besi dan vitamin A. Sebutan untuk masalah gizi KEP bila dilihat dari berat badan menurut usia yaitu underweight, dilihat dari tinggi badan menurut usia yaitu stunting, dan bila dilihat dari berat badan dan tinggi badan yaitu wasting. Masalah gizi kedua dari sisi asupan adalah kekurangan vitamin dan mineral yaitu micronutrient deficiencies. Kedua kondisi ini dapat memiliki konsekuensi negatif yang serius untuk kesehatan fisik dan mental. ${ }^{18-19}$

Nampaknya masalah gizi KEP ini belum mendapatkan penanganan yang baik bagi balita di Desa Mekargalih, yang tercermin dari tidak membaiknya prevalensi underweight dan stunting pada dua masa penelitian potong silang yakni 2012 dan 2015. Upaya perbaikan gizi masyarakat bertujuan untuk meningkatkan mutu gizi perseorangan dan masyarakat, antara lain melalui perbaikan pola konsumsi makanan, perbaikan perilaku sadar gizi,peningkatan akses dan mutu pelayanan gizi serta kesehatan sesuai dengan kemajuan ilmu dan teknologi. Perbaikan status gizi membutuhkan penanganan berkesinambungan dan membutuhkan ketekunan mengingat hasil yang diharapkan belum tentu dapat dicapai dalam waktu yang singkat.

Peran bidan di masyarakat sangat dibutuhkan, karena bidan berperan sebagai pelaksana, pengelola, pendidik, sekaligus peneliti. Permasalahan gizi merupakan masalah kesehatan masyarakat yang berakar dari individu, maka bidan harus melakukan pendekatan perbaikan gizi ini berbasis individu, keluarga, dan masyarakat, serta melakukan asuhan yang bermutu dan berkualitas. ${ }^{17,19}$ Bidan juga dapat melakukan kegiatan surveilans gizi. Kegiatan surveilans gizi bermanfaat untuk memberikan informasi pencapaian kinerja dalam rangka pengambilan tindakan segera, perencanaan jangka pendek dan menengah serta perumusan kebijakan, baik di kabupaten/kota, provinsi dan pusat. ${ }^{17,19}$

Keterbatasan penelitian ini terletak pada belum adanya data mengenai pemahaman dan praktik pola asuh pemberian makanan pada balita usia 3-5 tahun dan informasi mengenai daya dukung praktik pemenuhan gizi yang cukup dan berimbang di desa Mekargalih. Hal yang masih perlu digali termasuk pemahaman ibu balita dalam memanfaatkan buku KIA tentang kebutuhan gizi berimbang pada balita, kondisi sosial ekonomi keluarga balita dengan gangguan gizi serta ketersediaan /potensi sumber bahan makan dan upaya optimalisasinya yang dapat diupayakan secara mandiri maupun bergotong royong masyarakat Desa Mekargalih.

\section{Simpulan}

Berdasarkan hasil penelitian, dapat disimpulkan :

1) Prevalensi berat-kurang (underweight) pada balita usia 3-5 tahun di Desa Mekargalih Kecamatan Jatinangor bulan Maret 2015 mencapai 10,8\% termasuk dalam katagori masalah kesehatan masyarakat tingkat sedang. Angka prevalensi ini meningkat dibandingkan tahun 2012.

2) Prevalensi pendek (stunting) pada balita usia 3-5 tahun di Desa Mekargalih Kecamatan Jatinangor bulan Maret 2015 mencapai $16,2 \%$, termasuk dalam katagori masalah kesehatan masyarakat tingkat rendah.

3) Prevalensi kurus (wasting) pada balita usia 3-5 tahun di Desa Mekargalih Kecamatan Jatinangor bulan Maret 2015 mencapai sebesar 7,8\%, termasuk dalam katagori masalah kesehatan masyarakat tingkat sedang.

4) Untuk gangguan gizi gabungan dilihat dari indikator $\mathrm{TB} / \mathrm{U}$ dengan $\mathrm{BB} /$ TB didapatkan 1 orang anak dengan status gizi pendek-sangat kurus

\section{Saran}

Dari hasil penelitian ini penulis merangkum beberapa saran berikut :

1) Masalah gangguan gizi di masyarakat Desa Mekargalih perlu mendapatkan perhatian khusus misalnya dengan membentuk satuan kelompok khusus pengelolaan balita dengan masalah gizi yang dapat dilakukan dengan melakukan kerjasama yang lebih erat antara 
anggota keluarga, kader dasa wisma dan tenaga kesehatan. Tugas seorang bidan desa cukup berat sehingga perlu didukung dengan memanfaatkan sumber daya tenaga kesehatan yang dapat digerakkan untuk membantu kegiatan tersebut, dalam hal ini Bidan muda dari Program Studi Diploma 4 Kebidanan Fakultas kedokteran Unpad.

2) Perlu dilakukan penetapan skala prioritas masalah gizi balita tingkat Desa Mekargalih agar pengarahan suber daya desa dapat menunjang upaya perbaikan gizi balita. Hal ini dapat dipayakan melalui koordinasi dengan jajaran pemerintah Desa Mekargalih.

3) Perlu disusun sebuah program intervensi pada balita yang mengalami gangguan gizi di Desa Mekargalih, melalui upaya yang inovatif, mendorong kemandirian keluarga dan kesinambungannya dalam mengatasi gangguan gisi dan mencegah terjadinya kembali gangguan gizi

\section{Daftar Pustaka}

1. Kementrian Kesehatan. Pusat data dan informasi profil kesehatan Indonesia 2012. Jakarta: Kementrian Kesehatan RI; 2013. hlm. 67.

2. de Onis M, Blossner M. WHO Global database on child growht and malnutrition. statistics 2014. Diakses pada 19 Juni 2014. Tersedia dari: http://whqlibdoc.who.int/ hq/1997/WHO_NUT_97.4.pdf?ua=1

3. Badan Penelitian dan̄ Pengembangan Kesehatan Kementrian Kesehatan RI. Riset kesehatan dasar 2013. Jakarta: Kementrian Kesehatan RI; 2013. hlm. 205, 11, 12, 13.

4. Pusat Data dan Informasi Sekretariat Jendral Kementrian Kesehatan Indonesia Data dan Informasi Tahun 2014 (Profil Kesehatan Indonesia). 2014. Kementrian Kesehatan RI; 2014:103-6.

5. Dinas Kesehatan Kabupaten Sumedang. Profil Puskesmas Jatinangor tahun 2012.

6. Chamidah AN. Deteksi Dini Gangguan Pertumbuhan dan Perkembangan Anak. Jurnal Pendidikan Khusus. 2009; 5(2):83-93.

7. Menteri Kesehatan Republik Indonesia Peraturan Menteri Kesehatan no 75 tahun 2013 Tentang Angka Kecukupan Gizi Yang Dianjurkan Bagi Bangsa Indonesia. 2015. Kementrian Kesehatan Republik Indonesia. 2015.

8. Devi M. Analisis Faktor-Faktor Yang Berpengaruh Terhadap Status gizi Balita di Pedesaan. Teknologi dan Kejuruan. 2010;33(2):183-92.
9. Gunawan G, Fadlyana E, Kusmil R. Hubungan Status Gizi dan Perkembangan Anak Usia 1-2 Tahun. Sari Pediatri. 2011;13(2):142-6.

10. Septiana R, Djannah RSN, Djamil MD. Hubungan Antara Pola Pemberian Makanan Pendamping Asi (MP-ASI) dan Status gizi Balita Usia 6-24 Bulan Di Wilayah Kerja Puskesmas Gedongtengan Yogyakarta. Jurnal Kesehatan Masyarakat. 2010:4(2):76-143.

11. Kania N. Stimulasi Tumbuh Kembang Anak Untuk Mencapai Tumbuh Kembang Anak Yang Optimal. Prosiding Seminar "Stimulasi Tumbuh Kembang Anak". 11 Maret 2006. Bandung. 2006.

12. Menteri Kesehatan Republik Indonesia. Peraturan Menteri Kesehatan no 1995 tahun 2010 Tentang Standar Pengukuran Antropometri Bagi Penentuan Gizi Anak. 2010. Kementrian Kesehatan Republik Indonesia. 2010.

13. WHO Multicentre Growth Reference Study Group.WHOChildGrowthStandards:Length/ height-for-age, weight-for-age, weight-forlength, weight-for-height and body mass index-for-age: Methods and development. Geneva, World Health Organization, 2006. Diakses tanggal 10 Januari 2014. Tersedia dari : http://www.who. int/childgrowth/ standards/technical_report/en/index.html

14. UNICEF Indonesia. Ringkasan kajian ibu dan anak Oktober 2012. Diakses pada 24 Juni 2014.Tersedia dari: http://www.unicef.org/indonesia/ id/A-6-B_Ringkasan_Kajian_Gizi.pdf

15. Welasasih BD, Wirjatmadi RB. ${ }^{-}$Beberapa Faktor yang Berhubungan dengan Status Gizi Balita Stunting. The Indonesian Journal of Public Health. 2012;8(3):99-104.

16. Direktorat Jendral Bina Gizi dan Kesehatan Ibu dan Anak. Pedoman Umum Gizi Seimbang. Jakarta: Kementrian Kesehatan RI; 2013. hlm.3, 5, 9, 31.

17. Badan Perencanaan Pembangunan Nasional (BAPPENAS). Rencana aksi nasional pangan dan gizi 2011-2015. Jakarta: Kementrian Perencanaan Pembangunan Nasional; 2011.

18. Kids Company Plate Pledge. The impact of malnutrition on children's physical and mental development 2012. Diakses padan 17 Juni 2014. Tersedia dari : http://www.kidscoplatepledge. org/wpcontent/uploads/2011/11/ platepledge-the-impact-of-nutrition.pdf.

19. Ismail G, Suffla S. Child safety, peace and health promotion, child malnutrition: MRCUNISA Safety \& Peace Promotion Research Unit; March,2013. Tersedia dari:http://www. mrc.ac.za/crime/ChildMalnutrition.pdf 